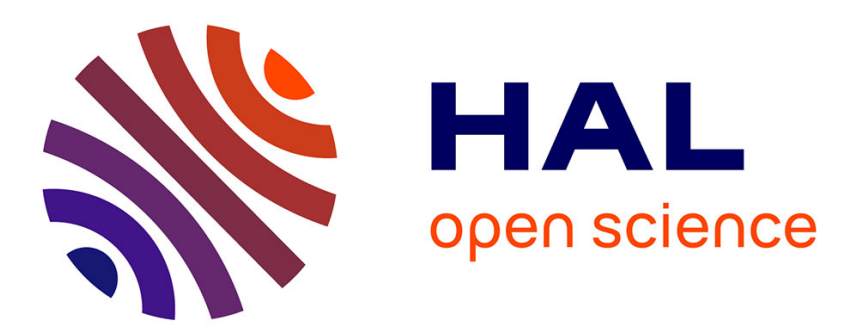

\title{
Litter identity mediates predator impacts on the functioning of an aquatic detritus-based food web
}

Jérémy Jabiol, Julien Cornut, Michaël Danger, Marion Jouffroy, Arnaud Elger, Eric Chauvet

\section{- To cite this version:}

Jérémy Jabiol, Julien Cornut, Michaël Danger, Marion Jouffroy, Arnaud Elger, et al.. Litter identity mediates predator impacts on the functioning of an aquatic detritus-based food web. Oecologia, 2014, vol. 176 ( $\left.\mathrm{n}^{\circ} 1\right)$, pp. 225-235. 10.1007/s00442-014-2990-y . hal-01142917

\section{HAL Id: hal-01142917 \\ https://hal.science/hal-01142917}

Submitted on 16 Apr 2015

HAL is a multi-disciplinary open access archive for the deposit and dissemination of scientific research documents, whether they are published or not. The documents may come from teaching and research institutions in France or abroad, or from public or private research centers.
L'archive ouverte pluridisciplinaire HAL, est destinée au dépôt et à la diffusion de documents scientifiques de niveau recherche, publiés ou non, émanant des établissements d'enseignement et de recherche français ou étrangers, des laboratoires publics ou privés. 


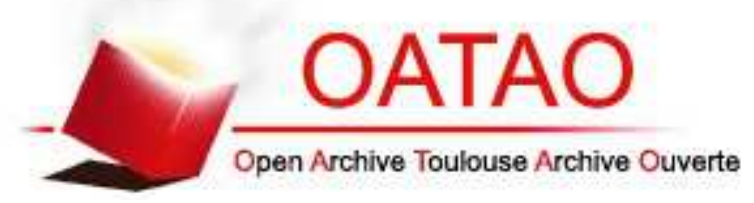

\section{Open Archive TOULOUSE Archive Ouverte (OATAO)}

OATAO is an open access repository that collects the work of Toulouse researchers and makes it freely available over the web where possible.

This is an author-deposited version published in : http://oatao.univ-toulouse.fr/ Eprints ID : 13701

To link to this article : DOI:10.1007/s00442-014-2990-y URL : http://dx.doi.org/10.1007/s00442-014-2990-y

To cite this version : Jabiol, Jérémy and Cornut, Julien and Danger, Michaël and Jouffroy, Marion and Elger, Arnaud and Chauvet, Eric Litter identity mediates predator impacts on the functioning of an aquatic detritus-based food web. (2014) Oecologia, vol. $176\left(\mathrm{n}^{\circ} 1\right)$. pp. 225-235. ISSN 0029-8549

Any correspondance concerning this service should be sent to the repository administrator: staff-oatao@ listes-diff.inp-toulouse.fr 


\title{
Litter identity mediates predator impacts on the functioning of an aquatic detritus-based food web
}

\author{
Jérémy Jabiol · Julien Cornut · Michaël Danger • \\ Marion Jouffroy $\cdot$ Arnaud Elger $\cdot$ Eric Chauvet
}

\begin{abstract}
During past decades, several mechanisms such as resource quality and habitat complexity have been proposed to explain variations in the strength of trophic cascades across ecosystems. In detritus-based headwater streams, litter accumulations constitute both a habitat and a resource for detritivorous macroinvertebrates. Because litter edibility (which promotes trophic cascades) is usually inversely correlated with its structural complexity (which weakens trophic cascades), there is a great scope for stronger trophic cascades in litter accumulations that are dominated by easily degradable litter species. However, it remains unclear how mixing contrasting litter species (conferring both habitat complexity and high quality resource) may influence top-down controls on communities and processes. In enclosures exposed in a second-order stream, we manipulated litter species composition by using two contrasting litter (alder and oak), and the presence-absence of a macroinvertebrate predator (Cordulegaster boltonii larvae), enabling it to effectively exert predation pressure, or not, on
\end{abstract}

Communicated by Barbara J. Downes.

J. Jabiol $(\bowtie) \cdot$ M. Jouffroy $\cdot$ A. Elger $\cdot$ E. Chauvet Université de Toulouse, UPS, INPT, EcoLab (Laboratoire Ecologie Fonctionnelle et Environnement), 118 route de Narbonne, 31062 Toulouse, France

e-mail: jeremy.jabiol@gmail.com

J. Jabiol · M. Jouffroy · A. Elger · E. Chauvet

CNRS, EcoLab, 31062 Toulouse, France

J. Cornut $\cdot$ M. Danger

LIEC, UMR 7360, Université de Lorraine, rue C. Bernard,

57070 Metz, France

J. Cornut $\cdot$ M. Danger

LIEC, UMR 7360, CNRS, rue C. Bernard, 57070 Metz, France detritivores (consumptive versus non-consumptive predation effects). Leaf mass loss, detritivore biomass and community structure were mostly controlled independently by litter identity and mixing and by predator consumption. However, the strength of predator control was mediated by litter quality (stronger on alder), and to a lesser extent by litter mixing (weaker on mixed litter). Refractory litter such as oak leaves may contribute to the structural complexity of the habitat for stream macroinvertebrates, allowing the maintenance of detritivore communities even when strong predation pressure occurs. We suggest that considering the interaction between top-down and bottom-up factors is important when investigating their influence on natural communities and ecosystem processes in detritus-based ecosystems.

Keywords Trophic cascades $\cdot$ Litter mixing $\cdot$ Litter decomposition $\cdot$ Shredder $\cdot$ Cordulegaster boltonii

\section{Introduction}

The study of trophic cascades has been one of the key issues of theoretical ecology during the past decades (Terborgh and Estes 2010). Trophic cascades refer to the top-down control exerted by predators, which limits primary consumers biomass and propagates through the food web to influence basal processes such as primary production or litter decomposition (Polis et al. 2000). In particular, identifying "what determines the strength of trophic cascades" (Borer et al. 2005) has received considerable attention during the past decade, as their magnitude soon appeared to be highly context-dependent and variable among ecosystem types (Strong 1992; Polis 1999; Halaj and Wise 2001; Shurin et al. 2002; Borer et al. 2005). For example, it has been repeatedly shown that trophic cascades were more prevalent in aquatic 
than in terrestrial ecosystems (Strong 1992; Shurin et al. 2002). This could be due to different non-exclusive mechanisms that drive the trophic transfer rates between primary producers and herbivores (Kurle and Cardinale 2011), such as larger differences in body size between resources and consumers (Shurin et al. 2006) and higher plant productivity (Shurin and Seabloom 2005), herbivore efficiency (Borer et al. 2005) or food quality (Hall et al. 2007) in aquatic than in terrestrial ecosystems.

The strength of trophic cascades may also depend on predation rates. The success of predators may depend on several parameters, which include the match between predator- versus prey-specific traits (e.g. predator hunting and prey predation avoidance strategies) (Chaves-Campos et al. 2011), as well as their habitat use, which determines their encountering rates (Schmitz et al. 2004). Habitat complexity may play a key role in improving prey escape rates and facilitating hiding (Kovalenko et al. 2012), resulting in decreased strength of predator control on prey populations (Price et al. 1980; Bruno et al. 2008). Interestingly, in ecosystems that rely on the decomposition of plant litter as a primary resource, such as forest floors or forested headwater streams, litter accumulations constitute both a habitat and a resource (Richardson 1992). On the one hand, the litter content in structural compounds (e.g. lignin) is one of the strongest factors that limit feeding rates by detritivores (Melillo et al. 1982; Gessner and Chauvet 1994). On the other hand, structurally heterogeneous accumulations are often less palatable for detritivores (Sanpera-Calbet et al. 2009). Thus, both the higher edibility and lower habitat structure of labile litter accumulations compared with refractory ones should promote stronger top-down controls by predators on detritivore biomass and decomposition process.

Litter accumulations in streams are usually distributed in discrete patches on the stream-bed, and often contain various litter species that likely exhibit contrasting physicochemical properties (Johnson and Covich 1997; Swan and Palmer 2004). Thus, litter accumulations that contain both fast- and slow-decomposing litter species may concomitantly constitute a structurally complex habitat and provide a suitable food resource. Assuming the mechanisms mentioned above, litter mixing should interact with top-down controls exerted by predators on stream detrital food-webs and contribute to maintain high process rates even in streams where top-down controls are prevalent. It is well known that litter mixing may influence decomposition, either positively or negatively (Gessner et al. 2010; Lecerf et al. 2011). However, although significant progress has been made during the past decade in the understanding of underlying mechanisms for litter mixing effects in streams (Gessner et al. 2010), the extent to which they are influenced by top-down controls is virtually unknown.
Finally, there is growing evidence that trophic cascades can arise from behaviorally mediated mechanisms (Schmitz et al. 1997; Schmitz 2008). These are based on the fact that prey are able to detect the presence of predators, and behave accordingly to decrease the predation risk (e.g. hiding, escape). In streams, macroinvertebrates are sensitive to predator chemical cues transported by stream water flow (Chivers and Smith 1998; Brönmark and Hansson 2012). Exposure of stream detritivores to predator chemical cues may lead to drift, hiding or reduced activity by detritivores with potentially strong consequences on leaf litter decomposition rates (Woodward and Hildrew 2002; Greig and McIntosh 2006; Boyero et al. 2008). Behavioral response to predation, by eliciting prey emigration and/or reducing their activity, may lead to trophic cascades that are as strong as those produced through consumptive trophic cascades on ecosystem processes (Schmitz et al. 1997), and could either reinforce or oppose the consumptive effect of predators (Werner and Peacor 2003).

Understanding the mechanisms that determine the strength of trophic cascades on prey communities and ecosystem processes is clearly needed in order to predict the potential effects of predator removal (Strong and Frank 2010; Terborgh and Estes 2010) and biodiversity loss in general (Hooper et al. 2005; Reiss et al. 2009). In this study, we used a well-studied and tractable detritus-based aquatic ecosystem (headwater stream) to evaluate the interactive effects between resource quality, diversity, and habitat structure on the strength of trophic cascades on detritivore communities, and on the key ecosystem process they perform (i.e. litter decomposition). Because both resource edibility and low habitat structure may increase the strength of trophic cascades, we expected to observe stronger control of predators in litter accumulation containing labile rather than refractory litter species (Table 1). By providing both high resource quality and habitat structure, mixed litter accumulations containing contrasting litter species should promote litter decomposition rates while decreasing the strength of topdown controls by predators (Table 1). Finally, we expected that the predation effect on leaf decomposition would, in part, be explained by detritivore emigration elicited by nontrophic predator-prey interactions (Table 1), i.e. maintained when consumption of prey by the predator is precluded.

\section{Materials and methods}

\section{Experimental set-up}

The study was carried out from 22 Jan to 24 Feb 2010 in the Rieutort, a 2nd order stream located in Montagne Noire, France $\left(02^{\circ} 22^{\prime} 59^{\prime \prime} \mathrm{E}, 43^{\circ} 23^{\prime} 33^{\prime \prime} \mathrm{N}\right.$; elevation $450 \mathrm{~m}$ a.s.1), 
Table 1 Hypothesized consequences of litter accumulations attributes on detritivore density, litter decomposition and strength of predator controls on these parameters through consumptive and non-consumptive pathways

\begin{tabular}{llll}
\hline & Labile litter & Refractory litter & Mix \\
\hline Food quality & + & - & + \\
Habitat complexity & - & + & + \\
Without predator & - High detritivore density & - Low detritivore density & - High detritivore density \\
& - High decomposition rates & - Low decomposition rates & - High decomposition rates \\
Consumptive effect of predators & - Lowered detritivore density & - Maintained detritivore density & - Maintained detritivore density \\
& - Lowered decomposition rate & - Maintained decomposition rate & - Maintained decomposition rate \\
Non-consumptive effect of preda- & - Lowered detritivore density or & - Maintained detritivore density or & - Maintained detritivore density or \\
tors & activity & activity & activity \\
& - Lowered decomposition rate & - Maintained decomposition rate & - Maintained decomposition rate \\
\hline
\end{tabular}

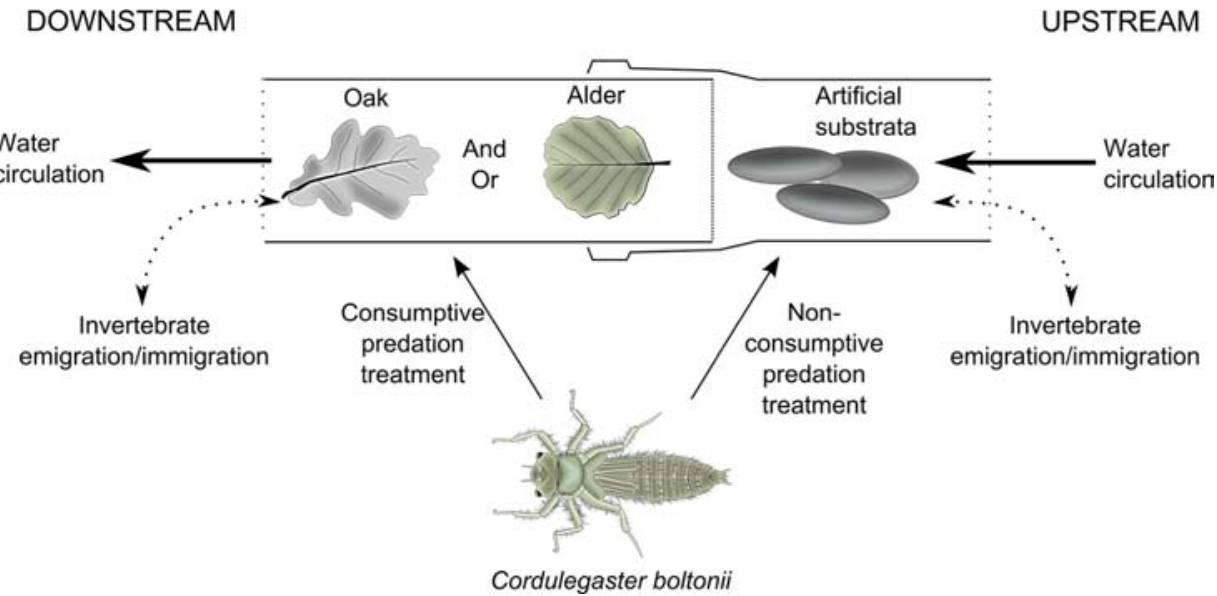

Fig. 1 Schematic representation of an enclosure showing the location of litter and odonate larvae in the different predation treatments (consumptive and non-consumptive)

in a pool-riffle-pool sequence extending over $500 \mathrm{~m}$. At baseflow, the stream was $3.5-4.5 \mathrm{~m}$ wide and $0.25-0.45 \mathrm{~m}$ deep in riffles. Water was circumneutral ( $\mathrm{pH}$ 6.9-7.4), average discharge was $540 \mathrm{~L} \mathrm{~s}^{-1}$ and temperature, constantly monitored using data loggers (Smart-Button; ACR System, Surrey, Canada), ranged from 2.6 to $7.6{ }^{\circ} \mathrm{C}$ (mean $5.3{ }^{\circ} \mathrm{C} \pm 2.1 \mathrm{SD}$ ) during the experiment. Surrounding vegetation consisted of mixed broadleaf tree species including oak (Quercus petraea (Matt.) Liebl.), alder (Alnus glutinosa (L.) Gaertn.), willow (Salix sp.), chestnut (Castanea sativa Mill.) and hazelnut (Corylus avellana L.).

Each experimental unit (Fig. 1) consisted of two PVC pipes $(7.5 \mathrm{~cm}$ diameter). PVC tubes fitted together to form a 25-cm-long tube. Additional 1-mm mesh was wedged between the two tube pieces, dividing each enclosure into two equal sections. Enclosures were closed at each end by 5-mm mesh, allowing macroinvertebrates to access both sections from the stream. The enclosures were fixed to the streambed and deployed with the mesh perpendicular to the current, so that one of the sections was positioned upstream from the other. The downstream section contained $4.00 \pm 0.04 \mathrm{~g}$ of litter belonging to two species, selected for their contrasting physico-chemical properties. Alder (A. glutinosa) and oak ( $Q$. petraea) were, respectively, selected as fast- and slow-decomposing species. Litter from these two species was collected in autumn 2009, just after abscission, and air-dried in the laboratory. Both single species and litter mixture treatments were applied, i.e. downstream section of the enclosures initially contained either $4 \mathrm{~g}$ of alder or oak (single species treatments) or $2 \mathrm{~g}$ of each species (mixture treatment).

Odonate larvae (Cordulegaster boltonii Donovan) were used as predator, as it was found to be the dominant and largest invertebrate predator in the experimental area (personal observation). Individuals of similar size (average length $32.1 \pm 2.2 \mathrm{~mm} \mathrm{SD}$, i.e. large enough to be unable to pass a 5-mm mesh) were collected in the Rieutort, $50 \mathrm{~m}$ downstream from the experimental site. They were enclosed in the tubes following three predation treatments: some tubes were free of odonate larvae, and some had one individual 
placed either in the downstream or in the upstream section of the enclosure (Fig. 1), the two latter treatments allowing consumptive or non-consumptive effects of the predator to occur, respectively (Peckarsky et al. 2008). While not preventing chemical cues from in-stream predators to access the enclosures, this design ensured that the odonate larvae introduced in the chambers were always the closest large predator in the predation treatments, and ensured a lower dilution of their chemical cues. Upstream sections received artificial leaves consisting in polyethylene sheets cut with size and thickness similar to that of real leaves, and pre-soaked before the experiment to extract any soluble chemicals, in order to provide habitat to odonate larvae. All possible combinations of litter (alder, oak and mixture) and predation treatments (consumptive, non-consumptive and odonate larvae-free) were combined, resulting in a full factorial design with nine litter $\times$ predation combinations. All combinations were replicated 10 times (i.e. 90 experimental units in total) in 5 blocks (i.e. each treatment combination replicated twice in each block) corresponding to distinct 20-m sections of the stream. Within each block, enclosures without odonate larvae were systematically placed in the upstream section of the block to ensure they did not receive chemical cues from the predator enclosures.

\section{Enclosures retrieval and laboratory procedures}

Enclosures were retrieved from the stream when alder single-species chambers reached approximately $40 \%$ of remaining litter mass, which was achieved after 33 days of exposure in the stream. The duration of the experiment was determined by extrapolation of the decomposition kinetics observed in six additional alder enclosures (without odonate larvae), retrieved by batches of two enclosures after 10, 15 and 25 days of exposure. For each enclosure, we removed macroinvertebrates from the remaining leaf material by using a $0.5-\mathrm{mm}$ sieve. Odonate larvae as well as macroinvertebrates from the upstream chamber were released in the stream while other macroinvertebrates from the downstream chamber were collected and fixed with $70 \%$ ethanol until processing. Leaves were washed individually to remove sediments and exogenous organic matter and sorted by species (for mixtures). They were then enclosed in zip-lock bags, frozen at $-20{ }^{\circ} \mathrm{C}$, lyophilized, and promptly weighed $( \pm 0.01 \mathrm{~g})$ to determine remaining dry mass. The leaf material was ground using a micro-hammer mill (Culatti, Zürich, Switzerland) with a $0.5-\mathrm{mm}$ mesh. Portions of leaf material of about $250 \mathrm{mg}$ were ashed at $550{ }^{\circ} \mathrm{C}$ for $4 \mathrm{~h}$ to determine the organic matter content. The proportion of leaf mass remaining in enclosures was expressed as the ratio of the ash-free dry mass (AFDM) between final and initial leaf litter. Initial AFDM as well as initial oven-dried mass by unit of air-dried mass were determined from ten unexposed batches of leaf litter per leaf species. Macroinvertebrates were identified to the genus level and sorted in functional feeding groups using identification keys (Waringer and Graf 1997; Tachet et al. 2000). Total detritivore biomass in each sample was determined after drying $\left(60^{\circ} \mathrm{C}, 48 \mathrm{~h}\right)$ and weighed to the nearest $0.01 \mathrm{mg}$.

\section{Statistical analyses}

Detritivore community composition was compared between treatments using non-metric multidimensional scaling (NMDS; Clarke 1993) and Permutational MANOVA (PERMANOVA; Anderson 2001) with Bray-Curtis ecological distance as a measure of dissimilarity between samples. NMDS is an ordination method that allows the mapping of samples in a multi-dimensional space while minimizing the difference between the measured ecological distance and the Euclidean distance between samples in the ordination space (Clarke 1993). PERMANOVA allows the partitioning of sums of squares of a multivariate data set with semi-metric distance matrices (e.g. Bray-Curtis ecological distance), and is a non-parametric analogous to the multivariate analysis of variance (MANOVA; Anderson 2001). The PERMANOVA model, based on 10,000 permutations, included standardized relative abundances of each detritivore species as a response matrix. Predictors were litter (three levels) and predation (three levels) treatments as well as their interaction. To account for a block effect, we restrained permutations within each block. For both analyses, data were standardized to illustrate differences in community composition but not differences in detritivore density.

The influence of litter and predator treatments were assessed using ANOVAs on log-transformed detritivore biomass ( $\mathrm{mg} \mathrm{g}^{-1}$ of litter AFDM) and leaf mass loss (\% of initial AFDM), as well as on log-transformed biomass ( $\mathrm{mg} \mathrm{g}^{-1}$ of litter AFDM) of dominating individual detritivore taxa (Trichoptera, Plecoptera and Gammarus). Litter and predator treatments were included in the analysis as a priori contrasts. For litter treatments, contrasts allowed comparing mixtures versus single species treatments (litter mixing contrast; $\mathrm{L}_{\mathrm{M}}$ ) and alder versus oak in single species treatments (litter identity contrast; $\mathrm{L}_{\mathrm{I}}$ ). Predation contrasts compared between the consumptive predation treatments versus control (consumptive predation contrast; $\mathrm{P}_{\mathrm{C}}$ ) and the non-consumptive predation treatment versus control (non- consumptive predation contrast; $\mathrm{P}_{\mathrm{NC}}$ ). Block and its interactions with all contrasts (litter and predation) were included as error terms (Schmid et al. 2002). Normality and homoscedasticity of residuals were checked graphically.

Moreover, we calculated an effect size (log ratio of means; Hedges et al. 1999) for predation effect on detritivore biomass and leaf mass loss, which is a commonly used alternative to null hypothesis significance testing approaches 
(Nakagawa and Cuthill 2007), and may generate a different and thus complementary interpretation of the results. Contrarily to ANOVA, it allows measuring and comparing the amplitude of predation and litter mixing effects between different combinations of treatment. Log ratios were calculated for each treatment combination as the ratio between average (across blocks) values in treatment (presence of predator in consumptive or non-consumptive treatment) and control (without odonate larvae) samples. Finally, effect sizes for litter mixing effect were calculated in the same way, based on the comparison of litter single species treatments (both alder and oak) with mixtures. Negative log ratios (i.e. mean difference $<1$ ) indicate a negative effect of predation or litter mixing on the given variable. Log ratios for which the $95 \%$ confidence interval $\left(\mathrm{CI}_{\mathrm{LR}}\right)$ overlap zero indicate the absence of significant effect of predation or litter mixing. All statistical analyses were performed using R 2.15 (R Development Core Team 2012) with packages 'vegan' and 'metafor'.

\section{Results}

Detritivore communities

Overall, the dominant taxa in our 90 enclosures were Gammarus, accounting for $42.5 \pm 2.5 \%$ (mean \pm SE) of individuals among detritivores, Potamophylax $(24.8 \pm 1.9 \%)$, Leuctra $(11.1 \pm 1.1 \%)$, Nemoura $(7.3 \pm 1.1 \%)$, and Sericostoma $(5.6 \pm 0.9 \%)$. Other taxa together accounted for only $8.0 \%$ of total detritivore individuals and belonged to Plecoptera and Trichoptera. Two-dimensional NMDS ordination (Fig. 2) and PERMANOVA (Table 2) allowed the identifying of two main groups determined by litter species identity and mixing, with oak single species treatments in the left part, and alder single species together with mixtures in the right part of the NMDS ordination (Fig. 2). Conversely, although alder-consumptive predation enclosures were apart from other alder and mixture treatments on the NMDS ordination, predation had no significant effect on community composition (Table 2).

Average $( \pm \mathrm{SE}, n=10)$ detritivore biomass ranged from $2.9 \pm 0.5 \mathrm{mg} \mathrm{g}^{-1}$ litter AFDM in oak-non consumptive enclosures to $36.2 \pm 9.1 \mathrm{mg} \mathrm{g}^{-1}$ litter AFDM in alder-odonate larvae-free treatments. Litter identity and mixing explained $41.9 \%$ of total variance of detritivore biomass with effects mainly due to oak enclosures, which significantly differed from alder and mixture treatments. However, a significant although contingent effect of predation was found. While non-significant as a main effect (Table 3), predation influenced detritivore biomass in interaction with block, and particularly through the interaction between consumptive predation contrast and litter identity, which resulted from an increased effect of predation

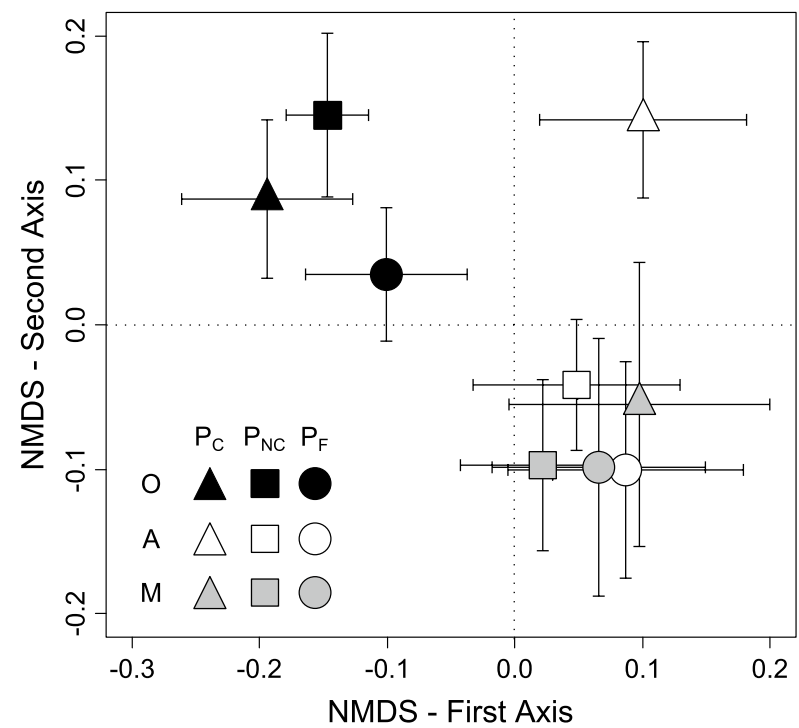

Fig. 2 Non-metric multi-dimensional scaling ordination (stress value: $19.7 \%$ ) on detritivore communities. Average coordinates $( \pm \mathrm{SE}, n=10)$ for each treatment are displayed. Capital letters on the legend indicate litter ( $O$ oak, $A$ alder, $M$ mix) and predation $\left(P_{C}\right.$ consumptive, $P_{N C}$ non-consumptive, $P_{F}$ predator-free) treatments

Table 2 Results of PERMANOVA based on 10,000 within-block permutations on Bray-Curtis ecological distance between samples

\begin{tabular}{lrrrr}
\hline & $d f$ & \multicolumn{1}{l}{$\mathrm{SS}$} & \multicolumn{1}{l}{$R^{2}$} & \multicolumn{1}{l}{$P$} \\
\hline Litter: mixing $\left(\mathrm{L}_{\mathrm{M}}\right)$ & 1 & 0.25 & 0.03 & $\mathbf{0 . 0 1 4}$ \\
Litter: identity $\left(\mathrm{L}_{\mathrm{I}}\right)$ & 1 & 0.60 & 0.08 & $\mathbf{0 . 0 0 1}$ \\
Predation: consumptive $\left(\mathrm{P}_{\mathrm{C}}\right)$ & 1 & 0.12 & 0.02 & 0.184 \\
Predation: non-consumptive $\left(\mathrm{P}_{\mathrm{NC}}\right)$ & 1 & 0.05 & 0.01 & 0.600 \\
$\mathrm{~L}_{\mathrm{M}} \times \mathrm{P}_{\mathrm{C}}$ & 1 & 0.04 & 0.01 & 0.670 \\
$\mathrm{~L}_{\mathrm{M}} \times \mathrm{P}_{\mathrm{NC}}$ & 1 & 0.03 & $<0.01$ & 0.755 \\
$\mathrm{~L}_{\mathrm{I}} \times \mathrm{P}_{\mathrm{C}}$ & 1 & 0.12 & 0.02 & 0.160 \\
$\mathrm{~L}_{\mathrm{I}} \times \mathrm{P}_{\mathrm{NC}}$ & 1 & $<0.01$ & $<0.01$ & 0.980 \\
Residuals & 81 & 6.00 & 0.83 & \\
\hline
\end{tabular}

Factors include litter species composition (contrasts: litter mixing and litter identity) and predation treatment (contrasts: consumptive and non-consumptive). All second-order interactions are included Significant $P$ values $(<0.05)$ in bold

in alder enclosures compared with oak and mixture treatments. Accordingly, effect sizes (log ratios of means) were strictly negative $\left(\mathrm{CI}_{\mathrm{Lr}}\right.$ : $\left.-2.05 ;-0.32\right)$ only in alder single species and consumptive predation treatments (Fig. 3c). Finally, although no interaction between predation and litter mixing was significant (Table 3), the effect of litter mixing on detritivore biomass was positive and almost significantly different from $0\left(\mathrm{CI}_{\mathrm{Lr}}:-0.04 ;+1.55\right)$ when the odonate was present in the consumptive predation treatment (Fig. 3c). 
Table 3 ANOVA results for detritivore biomass and leaf mass loss

Factors include litter species composition (contrasts: litter mixing and litter identity) and predation treatment (contrasts: consumptive and non-consumptive). Block effect is included as an error term, as well as all interactions it involves. Column E/F indicates whether the factor is a fixed or error term. Each fixed term is tested against the following error term, and error terms are tested against residuals

Significant $P$ values $(<0.05)$ in bold

Fig. 3 Left panels a average detritivore biomass $\left(\mathrm{mg} \mathrm{g}^{-1}\right.$ of litter AFDM) and b leaf mass loss ( $\%$ of initial AFDM) $( \pm \mathrm{SE}$ $n=10)$ in the different predation and litter treatments. Right panels $\log$ ratios and $95 \%$ confidence intervals for predation and litter mixing effects on $\mathbf{c}$ detritivore biomass and $\mathbf{d}$ leaf mass loss. In each panel, log ratios are sorted from the highest to the lowest

\begin{tabular}{|c|c|c|c|c|c|c|}
\hline & \multirow[t]{2}{*}{$\mathrm{E} / \mathrm{F}$} & \multirow[t]{2}{*}{$d f$} & \multicolumn{2}{|c|}{$\begin{array}{l}\text { Detritivore biomass } \\
\left(\mathrm{mg} \mathrm{g}^{-1} \text { of litter }\right. \\
\text { AFDM })\end{array}$} & \multicolumn{2}{|c|}{$\begin{array}{l}\text { Leaf mass loss } \\
\text { (\% of initial } \\
\text { AFDM) }\end{array}$} \\
\hline & & & SS & $P$ & SS & $P$ \\
\hline Block & E & 4 & 5.9 & 0.017 & 0.2 & 0.036 \\
\hline Litter: mixing $\left(\mathrm{L}_{\mathrm{M}}\right)$ & $\mathrm{F}$ & 1 & 4.6 & 0.031 & 2.7 & $<0.001$ \\
\hline Litter: identity $\left(\mathrm{L}_{\mathrm{I}}\right)$ & $\mathrm{F}$ & 1 & 36.0 & $<0.001$ & 23.7 & $<0.001$ \\
\hline Block $\times$ litter & $\mathrm{E}$ & 8 & 5.4 & 0.169 & 0.2 & 0.346 \\
\hline Predation: consumptive $\left(\mathrm{P}_{\mathrm{C}}\right)$ & $\mathrm{F}$ & 1 & 5.4 & 0.068 & 0.4 & 0.007 \\
\hline Predation: non- consumptive $\left(\mathrm{P}_{\mathrm{NC}}\right)$ & $\mathrm{F}$ & 1 & 0.3 & 0.608 & $<0.1$ & 0.435 \\
\hline Block $\times$ predation & $\mathrm{E}$ & 8 & 9.7 & 0.015 & 0.2 & 0.160 \\
\hline $\mathrm{L}_{\mathrm{M}} \times \mathrm{P}_{\mathrm{C}}$ & $\mathrm{F}$ & 1 & 0.4 & 0.338 & $<0.1$ & 0.462 \\
\hline $\mathrm{L}_{\mathrm{M}} \times \mathrm{P}_{\mathrm{NC}}$ & $\mathrm{F}$ & 1 & 0.2 & 0.468 & $<0.1$ & 0.632 \\
\hline $\mathrm{L}_{\mathrm{I}} \times \mathrm{P}_{\mathrm{C}}$ & $\mathrm{F}$ & 1 & 2.5 & 0.025 & $<0.1$ & 0.263 \\
\hline $\mathrm{L}_{\mathrm{I}} \times \mathrm{P}_{\mathrm{NC}}$ & $\mathrm{F}$ & 1 & 0.1 & 0.627 & $<0.1$ & 0.560 \\
\hline Block $\times$ litter $\times$ predation & $\mathrm{E}$ & 16 & 6.5 & 0.557 & 0.3 & 0.600 \\
\hline Residuals & E & 45 & 19.8 & & 0.8 & \\
\hline
\end{tabular}

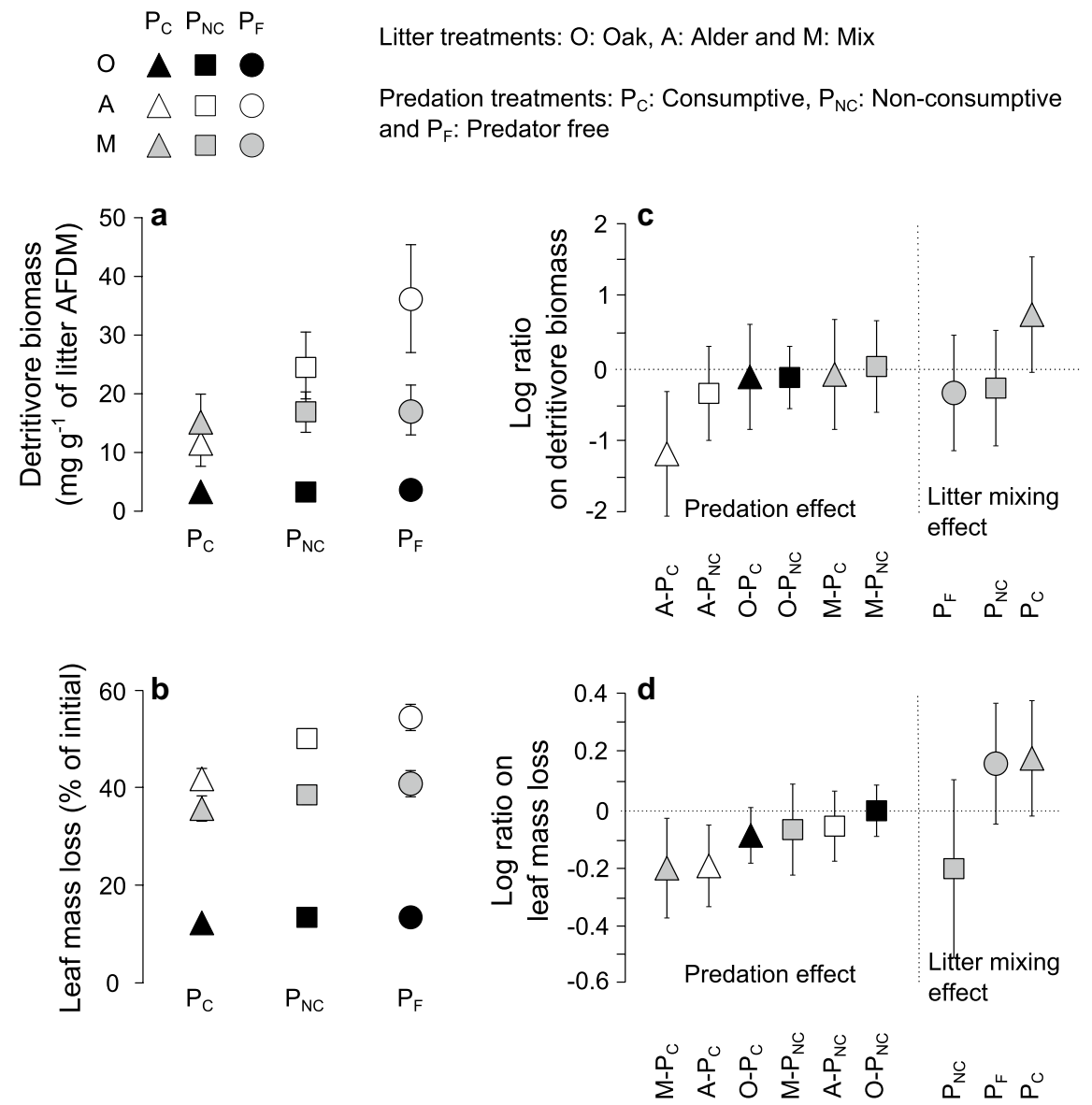

Predation and litter treatment effects on detritivore biomass differed among detritivore taxa (Table 4; Fig. 4). Trichoptera, which dominated communities in terms of biomass, were influenced by litter identity and mixing, as well as by consumptive effect of the predator (Fig. 4a, d). As observed for total detritivore biomass, the 
Table 4 ANOVA results for detritivore biomass ( $\mathrm{mg} \mathrm{g}^{-1}$ of litter AFDM) of the three dominant detritivore taxa (Gammarus, Plecoptera and Trichoptera)

\begin{tabular}{|c|c|c|c|c|c|c|c|c|}
\hline & \multirow[t]{2}{*}{$\mathrm{E} / \mathrm{F}$} & \multirow[t]{2}{*}{$d f$} & \multicolumn{2}{|c|}{ Trichoptera } & \multicolumn{2}{|c|}{ Plecoptera } & \multicolumn{2}{|c|}{ Gammarus } \\
\hline & & & SS & $P$ & SS & $P$ & SS & $P$ \\
\hline Block & E & 4 & 5.1 & 0.078 & 0.2 & 0.373 & 4.8 & 0.026 \\
\hline Litter: mixing $\left(\mathrm{L}_{\mathrm{M}}\right)$ & $\mathrm{F}$ & 1 & 5.9 & 0.024 & $<0.1$ & 0.519 & 0.1 & 0.693 \\
\hline Litter: identity $\left(\mathrm{L}_{\mathrm{I}}\right)$ & $\mathrm{F}$ & 1 & 42.3 & $<0.001$ & 2.3 & $<0.001$ & 4.4 & 0.020 \\
\hline Block $\times$ litter & $\mathrm{E}$ & 8 & 6.1 & 0.250 & 0.3 & 0.722 & 4.3 & 0.242 \\
\hline Predation: consumptive $\left(\mathrm{P}_{\mathrm{C}}\right)$ & $\mathrm{F}$ & 1 & 6.9 & 0.040 & $<0.1$ & 0.431 & 1.3 & 0.388 \\
\hline Predation: non-consumptive $\left(\mathrm{P}_{\mathrm{NC}}\right)$ & $\mathrm{F}$ & 1 & 0.6 & 0.480 & $<0.1$ & 0.475 & 0.3 & 0.678 \\
\hline Block $\times$ predation & $\mathrm{E}$ & 8 & 9.2 & 0.065 & 0.3 & 0.687 & 12.1 & 0.002 \\
\hline $\mathrm{L}_{\mathrm{M}} \times \mathrm{P}_{\mathrm{C}}$ & $\mathrm{F}$ & 1 & 0.8 & 0.209 & $<0.1$ & 0.907 & $<0.1$ & 0.991 \\
\hline $\mathrm{L}_{\mathrm{M}} \times \mathrm{P}_{\mathrm{NC}}$ & $\mathrm{F}$ & 1 & 0.2 & 0.550 & $<0.1$ & 0.371 & 0.8 & 0.282 \\
\hline $\mathrm{L}_{\mathrm{I}} \times \mathrm{P}_{\mathrm{C}}$ & $\mathrm{F}$ & 1 & 3.1 & 0.021 & $<0.1$ & 0.916 & 0.6 & 0.355 \\
\hline $\mathrm{L}_{\mathrm{I}} \times \mathrm{P}_{\mathrm{NC}}$ & $\mathrm{F}$ & 1 & 0.2 & 0.504 & $<0.1$ & 0.445 & $<0.1$ & 0.957 \\
\hline Block $\times$ litter $\times$ predation & $\mathrm{E}$ & 16 & 7.6 & 0.648 & 0.9 & 0.318 & 10.5 & 0.089 \\
\hline Residuals & $\mathrm{E}$ & 45 & 25.7 & & 2.3 & & 17.7 & \\
\hline
\end{tabular}

Factors include litter species composition (contrasts: litter mixing and litter identity) and predation treatment (contrasts: consumptive and nonconsumptive). Block effect is included as an error term, as well as all interactions it involves. Column E/F indicates whether the factor is a fixed or error term. Each fixed term is tested against the following error term, and error terms are tested against residuals

Significant $P$ values $(<0.05)$ in bold

interaction between the consumptive effect of the predator and litter identity was significant. Indeed, predation effect on Trichoptera biomass was the strongest in alder enclosures with consumptive predation $\left(\mathrm{CI}_{\mathrm{Lr}}:-2.31\right.$; -0.52). Moreover, detritivorous Trichoptera were significantly more abundant in litter mixtures than in single species treatments when consumptive effect of the odonate was allowed $\left(\mathrm{CI}_{\mathrm{Lr}}:+0.09 ;+1.85\right)$ (Fig. $\left.4 d\right)$. In contrast, Plecoptera biomass varied with litter identity but neither with litter mixing nor predation treatments (Table 4; Fig. 4b, e), although predation effect was significant in oak enclosures with direct predation $\left(\mathrm{CI}_{\mathrm{Lr}}:-2.03\right.$; -0.19). Finally, Gammarus biomass was only related to litter identity (Table 4; Fig. 4c, f). Predation effect, although of larger amplitude than in other invertebrate taxa $\left(\mathrm{CI}_{\mathrm{Lr}}\right.$ : $-3.28 ;+0.29$ in alder-consumptive predation enclosures), was non-significant in relation with the high between-block variation (Table 4).

\section{Leaf mass loss}

The highest leaf mass loss was observed in alder-odonate larvae free enclosures $(53.1 \pm 2.7 \%$ of initial leaf mass loss, mean $\pm \mathrm{SE}, n=10$ ). The lowest occurred in oakconsumptive predation with $12.4 \pm 0.5 \%$ leaf mass loss. Leaf mass loss depended mostly on litter identity and mixing (Table 3; Fig. 3b, d). Overall, oak treatments exhibited the lowest leaf mass loss $(13.1 \pm 0.3 \%)$ and alder the highest $(51.0 \pm 1.5 \%)$. Decomposition of mixtures was intermediate $(37.4 \pm 1.4 \%$ leaf mass loss), but closer to that of alder, resulting in a significant effect of litter mixing. Predation also significantly influenced litter decomposition through consumptive (Table 4) but not non-consumptive mechanisms, with lower leaf mass loss in consumptive predation $(30.5 \pm 2.7 \%)$ than in non-consumptive predation $(33.5 \pm 3.0 \%)$ and odonate larvae-free $(35.7 \pm 3.4 \%)$ treatments. Although the non-consumptive effect of predation on leaf mass loss did not differ significantly from consumptive effects, leaf mass loss in non-consumptive predation enclosures was intermediate between consumptive predation and odonate larvae-free treatments. Finally, consumptive predation effect was significant in alder $\left(\mathrm{CI}_{\mathrm{Lr}}:-0.33 ;-0.05\right)$ and mixed $\left(\mathrm{CI}_{\mathrm{Lr}}:-0.38 ;-0.02\right)$ but not in oak enclosures $\left(\mathrm{CI}_{\mathrm{Lr}}\right.$ : $-0.19 ;+0.01)$ (Fig. 3d).

\section{Discussion}

Both detritivore biomass and litter decomposition were mainly independently influenced by litter quality and mixing and the presence of a predator through consumptive mechanisms. This notwithstanding, some interactions between top-down and bottom-up factors influenced prey communities and the ecosystem process rate we targeted (litter decomposition). Specifically, we found that the strength of predator control on detritivore biomass (and to a lesser extent leaf litter decomposition) could be influenced by the species composition of litter accumulations. 
Fig. 4 Left panels average detritivore biomass $\left(\mathrm{mg} \mathrm{g}^{-1}\right.$ of litter AFDM) $( \pm \mathrm{SE}, n=10)$ for a Trichoptera, b Plecoptera and $\mathbf{c}$ Gammarus as a function of predation and litter treatments. Right panels Log ratios and $95 \%$ confidence intervals for predation and litter mixing effects on $\mathbf{d}$ Trichoptera, $\mathbf{e}$ Plecoptera and $\mathbf{f}$ Gammarus biomass. In each panel, log ratios are sorted from the highest to the lowest

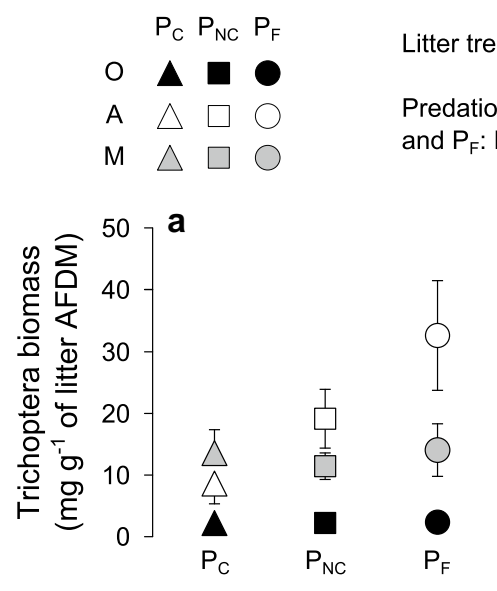

Litter treatments: O: Oak, A: Alder and M: Mix

Predation treatments: $P_{\mathrm{C}}$ : Consumptive, $\mathrm{P}_{\mathrm{NC}}$ : Non-consumptive and $P_{F}$ : Predator free
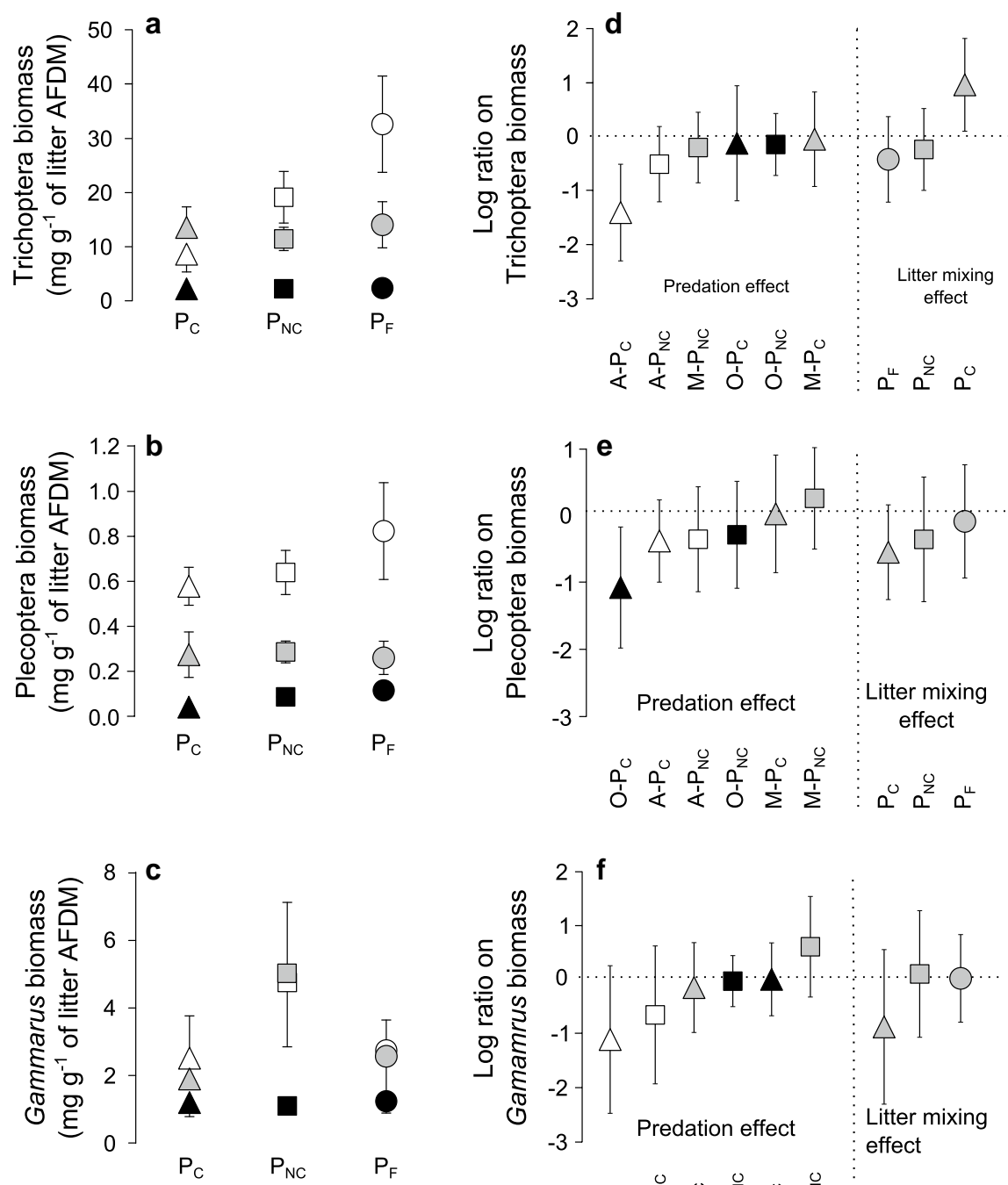

Litter identity and mixing were unsurprisingly the strongest factors controlling detritivore biomass, community structure and leaf litter decomposition. As detritivores are able to discriminate between litter species of contrasting quality (Graça 2001), they preferentially colonize high rather than low quality (e.g. lignin-rich) litter species, which strongly constrains their feeding rates (Hladyz et al. 2009). Higher detritivore densities and per capita feeding rates on high quality litter may thus act synergistically to determine their higher decomposition rates compared with low quality litter. Moreover, in accordance with previous results, we found that litter mixing could influence detritivore communities (Kominoski and Pringle 2009), as well as decomposition rates (Lecerf et al. 2005; Gessner et al. 2010), which may result from selective feeding on the preferred litter species within the mixture (Swan and Palmer 2006). Predation also significantly altered detritivore biomass and, to a lesser extent, community composition. In accordance with our observation that $C$. boltonii fed on Trichoptera larvae in our enclosures (personal observation), these effects were primarily due to decreased Trichoptera biomass by predation, and occurred when a consumptive effect of the predator was enabled. Leaf-eating Trichoptera dominated detritivore communities, and the depletion of their biomass through C. boltonii consumption may have largely contributed to the decreased litter decomposition. Several studies reported 
cascading effects of stream predators on litter decomposition rates through both consumptive and non-consumptive mechanisms (Greig and McIntosh 2006; Woodward et al. 2008; Buria et al. 2010). In accordance with previous studies (Woodward and Hildrew 2002), we found that the effect of $C$. boltonii on detritivore communities and litter decomposition was primarily due to consumptive mechanisms, suggesting that chemical cues released by the predator had little effect on prey emigration.

More importantly, the effect of predator on detritivore biomass through consumptive mechanism strongly depended on the species composition of litter accumulations. In particular, it was only significant in alder but was non-significant on oak and mixed enclosures. This strongly suggests that the presence of oak litter within the litter accumulations decreased the predation efficiency on detritivores. As expected in our hypotheses, this is likely due to an increased habitat structure conferred by refractory litter which may decrease predator effect on detritivores (Diehl 1992; Kalinkat et al. 2012; but see Reice 1991; Ruetz et al. 2006). Similarly, the predation effects (i.e. log ratios) on leaf mass were significant only in alder and mixtures but not in oak litter treatments, although absolute differences between litter substrates remained modest as suggested by the nonsignificance of the interaction between predator and litter contrasts. In our study, different strength of predation effects between litter treatments could have been exacerbated by the contrasted food quality between alder and oak litter. In accordance with the "food quality hypothesis" (Hall et al. 2007), high digestibility of the resource in alder enclosures (compared with oak) could have promoted per capita consumption rates, thus amplifying the propagation of the topdown effect through detritivore biomass.

To the contrary, it appears that the propagation of topdown effects from detritivore biomass to the litter decomposition process was not straightforward. Actually, while detritivore biomass was maintained in mixtures (compared with alder single species treatments), leaf mass loss decreased to the same extent than in alder single species treatments as a result of predator presence. This suggests that detritivores, although relatively abundant in mixtures, reduced their consumption rates, which is likely due to a behaviorally mediated (i.e. non-consumptive) effect of the predator presence. Given the absence of predator effects in our non-consumptive treatment, this effect probably occurred in the consumptive predation treatment only. Our experimental design only evaluated the non-consumptive predation effects that propagate through chemical cues, which has been repeatedly shown as an important mechanism in running waters (Chivers and Smith 1998; Brönmark and Hansson 2012). It did not allow non-consumptive effects that may arise when the predator is actively foraging at the immediate surroundings of prey (e.g. visual mediation, movement detection) and that may have played an important role in our consumptive predation treatment.

Predation effect ultimately depended on the block, which may be explained by between-blocks variations in environmental conditions but may also reflect between-blocks differences in detritivore community composition. Different detritivore taxa were not influenced by predation to the same extent, which likely reflects a higher predation rate by $C$. boltonii on the dominant Trichoptera larvae compared with other potential prey species. It could reflect both a higher encountering rate between $C$. boltonii and Trichoptera, or a prey selectivity by $C$. boltonii for slowly moving Trichoptera (e.g. preferred to good swimmer Gammarus), or finally some differences among detritivore species in predation avoidance strategies (e.g. emigration, reduced activity and/ or hiding). In diverse natural communities, where several prey and predator species co-occur, specific predator-prey interactions (i.e. between a given prey and a given predator species) may differ in strength from each other as a result of predator preferences, prey versus predator strategy and life history traits (Schmitz et al. 2004; Chaves-Campos et al. 2011). The structure of prey and predator communities, as well as the structure of the predator-prey interaction network may thus strongly influence the strength of top-down control on detritivore biomass, with possibly important consequences on ecosystem processes such as litter decomposition. Natural factors that may alter the relationships between consumers and their resources (i.e. predator-detritivores and detritivores-litter) include the effect of time. For instance, changes in detritivore community composition, as well as an increase of their individual body mass, are usually observed from autumn to spring. In the meantime, refractory litter species get increasingly soft with time as a result of microbial activity, and labile species typically become scarce in winter. As a result, it is likely that the propagation of top-down controls to litter decomposition becomes stronger from autumn to spring, or even over the span of an experiment, as a result of higher per capita litter consumption by detritivores and higher predation rates.

To conclude, we found that resource diversity and predator presence may have similarly strong (although possibly opposite) effects on communities and ecosystem processes. Moreover, we found that top-down controls may be mediated by bottom-up properties of the system. This suggests that any species loss within the food web may influence communities and ecosystem processes, and that the consequence of concomitant species loss at several trophic levels cannot be predicted from responses at single trophic level. Habitat structure may have been the major factor mediating the strength of our stream trophic cascade, although further studies would be necessary to draw definitive conclusions about the mediation of top-down controls by litter accumulation properties. Using a broader array of leaf 
species exhibiting variable sets of litter traits (and of varying edibility) would certainly help to decide on the influence of the physical structure and resource edibility conferred by litter accumulations. Overall, our results suggest that if allochthonous subsidies may promote the strength of trophic cascades as suggested by theoretical models (Leroux and Loreau 2008), they can also relax the control of prey communities by predators depending on their structural quality.

Acknowledgments We are grateful to Mark Gessner, Markus Schindler and Brendan McKie who designed and built the enclosures used in this experiment, André Frainer Barbosa for constructive discussion about the experimental design, as well as Barbara Downes and several anonymous referees for their very helpful comments and suggestions on the manuscript. We also greatly appreciate the technical assistance of Sylvain Lamothe and Didier Lambrigot in the field and laboratory. Finally, we thank Jean-Claude Arnaud, Président du syndicat des riverains et pêcheurs de Roquefère et de Labastide, who kindly allowed us access to the Rieutort.

\section{References}

Anderson MJ (2001) A new method for non-parametric multivariate analysis of variance. Austral Ecol 26:32-46. doi:10.111 1/j.1442-9993.2001.01070

Borer ET, Seabloom EW, Shurin JB, Anderson KE, Blanchette CA, Broitman B, Cooper SD, Halpern BS (2005) What determines the strength of a trophic cascade? Ecology 86:528-537. doi:10.1890/03-0816

Boyero L, Rincón PA, Pearson RG (2008) Effects of a predatory fish on a tropical detritus-based food web. Ecol Res 23:649-655. doi:10.1007/S11284-007-0424-6

Brönmark C, Hansson L-A (2012) Chemical ecology in aquatic systems. Oxford University Press, Oxford

Bruno JF, Boyer KE, Duffy JE, Lee SC (2008) Relative and interactive effects of plant and grazer richness in a benthic marine community. Ecology 89:2518-2528. doi:10.1890/07-1345.1

Buria L, Albariño R, Díaz Villanueva V, Modenutti B, Balseiro E (2010) Does predation by the introduced rainbow trout cascade down to detritus and algae in a forested small stream in Patagonia? Hydrobiologia 651:161-172. doi:10.1007/s10750-010-0293-9

Chaves-Campos J, Johnson SG, Hulsey CD (2011) Spatial geographic mosaic in an aquatic predator-prey network. PLoS ONE 6:e22472. doi:10.1371/journal.pone.0022472

Chivers DP, Smith RJF (1998) Chemical alarm signalling in aquatic predator-prey systems: a review and prospectus. Ecoscience 5:338-352

Clarke KR (1993) Non-parametric multivariate analyses of changes in community structure. Aust J Ecol 18:117-143. doi:10.1111/j. 1442-9993.1993.tb00438.x

Diehl S (1992) Fish predation and benthic community structure: the role of omnivory and habitat complexity. Ecology 73:1646-1661

Gessner MO, Chauvet E (1994) Importance of stream microfungi in controlling breakdown rates of leaf litter. Ecology 75:1807-1817

Gessner MO, Swan CM, Dang CK, McKie BG, Bardgett RD, Wall DH, Hättenschwiler S (2010) Diversity meets decomposition. Trends Ecol Evol 25:372-380. doi:10.1016/j.tree.2010.01.010

Graça MAS (2001) The role of invertebrates on leaf litter decomposition in streams - a review. Int Rev Hydrobiol 86:383-393. doi:10.1002/1522-2632(200107)86:4/5<383:AID-IROH383>3.0. CO;2-D
Greig HS, McIntosh AR (2006) Indirect effects of predatory trout on organic matter processing in detritus-based stream food webs. Oikos 112:31-40. doi:10.1111/j.0030-1299.2006.14219.x

Halaj J, Wise DH (2001) Terrestrial trophic cascades: how much do they trickle? Am Nat 157:262-281. doi:10.1086/319190

Hall SR, Shurin JB, Diehl S, Nisbet RM (2007) Food quality, nutrient limitation of secondary production, and the strength of trophic cascades. Oikos 116:1128-1143. doi:10.1111/j.0030-1299.2007.15875.x

Hedges LV, Gurevitch J, Curtis PS (1999) The meta-analysis of response ratios in experimental ecology. Ecology 80:1150-1156. doi:10.1890/0012-9658(1999)080

Hladyz S, Gessner MO, Giller PS, Pozo J, Woodward G (2009) Resource quality and stoichiometric constraints on stream ecosystem functioning. Freshw Biol 54:957-970. doi:10.1111/j.1365-2427.2008.02138.x

Hooper DU, Chapin FS III, Ewel JJ, Hector A, Inchausti P, Lavorel S, Lawton JH, Lodge DM, Loreau M, Naeem S, Schmid B, Setälä H, Symstad AJ, Vandermeer J, Wardle DA (2005) Effects of biodiversity on ecosystem functioning: a consensus of current knowledge. Ecol Monogr 75:3-35. doi:10.1890/04-0922

Johnson S, Covich A (1997) Scales of observation of riparian forests and distributions of suspended detritus in a prairie river. Freshw Biol 37:163-175. doi:10.1046/j.1365-2427.1997.00150.x

Kalinkat G, Brose U, Rall BC (2012) Habitat structure alters topdown control in litter communities. Oecologia 172:877-887. doi:10.1007/s00442-012-2530-6

Kominoski JS, Pringle CM (2009) Resource-consumer diversity: testing the effects of leaf litter species diversity on stream macroinvertebrate communities. Freshw Biol 54:1461-1473. doi:10.1111/j.1365-2427.2009.02196.x

Kovalenko KE, Thomaz SM, Warfe DM (2012) Habitat complexity: approaches and future directions. Hydrobiologia 658:1-17. doi:10.1007/s10750-011-0974-z

Kurle CM, Cardinale BJ (2011) Ecological factors associated with the strength of trophic cascades in streams. Oikos 120:1897-1908. doi:10.1111/j.1600-0706.2011.19465.x

Lecerf A, Dobson M, Dang CK, Chauvet E (2005) Riparian plant species loss alters trophic dynamics in detritus-based stream ecosystems. Oecologia 146:432-442

Lecerf A, Marie G, Kominoski JS, Leroy CJ, Bernadet C, Swan CM (2011) Incubation time, functional litter diversity, and habitat characteristics predict litter mixing effects on decomposition. Ecology 92:160-169. doi:10.1890/10-0315.1

Leroux SJ, Loreau M (2008) Subsidy hypothesis and strength of trophic cascades across ecosystems. Ecol Lett 11:1147-1156. doi:10.1111/j.1461-0248.2008.01235.x

Melillo JM, Aber JD, Muratore JF (1982) Nitrogen and lignin control of hardwood leaf litter decomposition dynamics. Ecology 63:621-626

Nakagawa S, Cuthill IC (2007) Effect size, confidence interval and statistical significance: a practical guide for biologists. Biol Rev 82:591-605. doi:10.1111/j.1469-185X.2007.00027.x

Peckarsky BL, Abrams PA, Bolnick DI, Dill LM, Grabowski JH, Luttbeg B, Orrock JL, Peacor SD, Preisser EL, Schmitz OJ, Trussell GC (2008) Revisiting the classics: considering nonconsumptive effects in textbooks examples of predator prey interactions. Ecology 89:2416-2425. doi:10.1890/07-1131.1

Polis GA (1999) Why are part of the world green? multiple factors control productivity and the distribution of biomass. Oikos $86: 3-15$

Polis GA, Sears ALW, Huxel GR, Strong DR, Maron J (2000) When is a trophic cascade a trophic cascade? Trends Ecol Evol 15:473-475

Price PW, Bouton CE, Gross P, McPheron BA, Thompson JN, Weis AE (1980) Interactions among three trophic levels: influence of plants on interactions between insects herbivores and natural ennemies. Annu Rev Ecol Syst 11:41-65. doi:10.1146/annurev .es.11.110180.000353 
R Development Core Team (2012) R: a language and environment for statistical computing. R Foundation for Statistical Computing, Vienna

Reice SR (1991) Effects of detritus loading and fish predation on leafpack breakdown and benthic macroinvertebrates in a woodland stream. J N Am Benthol Soc 10:42-56

Reiss J, Bridle JR, Montoya JM, Woodward G (2009) Emerging horizons in biodiversity and ecosystem functioning research. Trends Ecol Evol 24:505-514. doi:10.1016/j.tree.2009.03.018

Richardson JS (1992) Food, microhabitat, or both? Macroinvertebrate use of leaf accumulations in a montane stream. Freshw Biol 27:169-176. doi:10.1111/j.1365-2427.1992.tb00531.x

Ruetz CR, Breen MJ, Vanhaitsma DL (2006) Habitat structure and fish predation: effects on invertebrate colonisation and breakdown of stream leaf packs. Freshw Biol 51:797-806. doi:10.1111/j.1365-2427.2006.01525.x

Sanpera-Calbet I, Lecerf A, Chauvet E (2009) Leaf diversity influences in-stream litter decomposition through effects on shredders. Freshw Biol 54:1671-1682. doi:10.1111/j.1365-2427.2009.02216.x

Schmid B, Hector A, Huston MA, Inchausti P, Nijs I, Leadley PW, Tilman D (2002) The design and analysis of biodiversity experiments. In: Loreau M, Naeem S, Inchausti P (eds) Biodiversity and ecosystem functioning: synthesis and perspectives. Oxford University Press, Oxford, pp 61-75

Schmitz OJ (2008) Effects of predator hunting mode on grassland ecosystem function. Science 319:952-954. doi:10.1126/ science. 1152355

Schmitz OJ, Beckerman AP, O'Brien KM (1997) Behaviorally mediated trophic cascades: effects of predation risk on food web interactions. Ecology 78:1388-1399

Schmitz OJ, Krivan V, Ovadia O (2004) Trophic cascades: the primacy of trait-mediated indirect interactions. Ecol Lett 7:153-163. doi:10.1111/j.1461-0248.2003.00560.x

Shurin JB, Seabloom EW (2005) The strength of trophic cascades across ecosystems: predictions from allometry and energetics. J Anim Ecol 74:1029-1038. doi:10.1111/j.1365-2656.2005.00999.x
Shurin JB, Borer ET, Seabloom EW, Anderson K, Blanchette CA, Broitman B, Cooper SD, Halpern BS (2002) A cross-ecosystem comparison of the strength of trophic cascades. Ecol Lett 5:785791. doi:10.1046/j.1461-0248.2002.00381.x

Shurin JB, Gruner JS, Hillebrand H (2006) All wet or dried up? Real differences between aquatic and terrestrial food webs. Proc R Soc Lond B 273:1-9. doi:10.1098/rspb.2005.3377

Strong DR (1992) Are trophic cascades all wet? Differentiation and donnor-control in speciose ecosystems. Ecology 73:747-754. doi: $10.2307 / 1940154$

Strong DR, Frank TF (2010) Human involvement in food webs. Annu Rev Environ Resour 35:1-23. doi:10.1146/annurevenviron-031809-133103

Swan CM, Palmer MA (2004) Leaf diversity alters litter breakdown in a piedmont stream. J N Am Benthol Soc 23:15-28. doi:10.1899/0887-3593(2004)023

Swan CM, Palmer MA (2006) Preferential feeding by an aquatic consumer mediates non-additive decomposition of speciose leaf litter. Oecologia 149:107-114. doi:10.1007/s00442-006-0436-x

Tachet H, Richoux P, Bournard M, Usseglio-Polatera P (2000) Invertébrés d'eau douce : systématique, biologie, écologie. CNRS Edition, Paris

Terborgh J, Estes JA (2010) Trophic cascades — predators, prey, and the changing dynamics of nature. Island Press, Washington

Waringer J, Graf W (1997) Atlas der österreichischen Köcherfliegenlarven. Facultas Universitätsverlag, Wien

Werner EA, Peacor SD (2003) A review of trait-mediated indirect interactions in ecological communities. Ecology 84:1083-1100. doi:10.1890/0012-9658(2003)084

Woodward G, Hildrew AG (2002) The impact of a sit-and-wait predator: separating consumption and prey emigration. Oikos 99:409418. doi:10.1034/j.1600-0706.2002.11210.x

Woodward G, Papantoniou G, Edwards F, Lauridsen RB (2008) Trophic trickles and cascades in a complex food web: impacts of a keystone predator on stream community structure and ecosystem processes. Oikos 117:683-692. doi:10.1111/j.0030-1299.2008.16500.x 